\title{
Development of a Solar Operated Blower for Forging Operation: An Initiative for Sustainable Livelihood of Rural Area
}

\author{
Debashree Debadatta Behera, R.C. Mohanty, A.M. Mohanty
}

\begin{abstract}
Blacksmith generally do the forging operation by hand which requires more time and have survived to exist in rural economy even today. Due to unavailability of electricity and limitation of modern energy sources, economic development of rural area lays extreme poverty line. Development of solar operated blacksmith blower gives a reliable and sustainable solution to blacksmith for their forging operation. This paper represents design and development of solar operated blacksmith blower which was eco-friendly, less time consuming and high efficiency. The main component of solar operated blower is charge controller, battery, solar panel, DC blower and a speed controller. Mathematical calculation had been done for sizing of solar panel, battery, and charge controller and speed controller. The regulation of supplement of air for forging operation with the help of speed controller is the unique design of this research.
\end{abstract}

Keywords: Forging, Solar panel, battery, charge controller, speed controller

\section{INTRODUCTION}

The rural economy in India is based on agricultural production and agro processing mostly in tiny scale or domestic units. A substantial majority of agricultural production emanates from small and medium land holdings. But the major issues faced by blacksmiths are:

1. Low income, low productivity and labour shortage.

2. Competition from industrial products, increased cost of raw materials and charcoal, unavailability of charcoal, shortage of labour, additional labour cost to operate the manual blower are all adding to the burden of blacksmiths making it difficult for them to depend on their traditional artisanal work for living.

Increasing the income levels and productivity is an essential measure to be attempted for the survival of this artisanal work. One of the most common issues faced by blacksmiths is shortage of labour to operate the manual blower and huge labour cost which takes away a significant portion of their income.

Revised Manuscript Received on February 05, 2020.

* Correspondence Author

Debashree Debadatta Behera*, Department of Mechanical Engineering , Centurion University of Technology and Management, Odisha, India, Email: debashree.behera@cutm.ac.in

R.C. Mohanty, Department of Mechanical Engineering, Centurion University of Technology and Management, Odisha, India, Email: rcmohanty@cutm.ac.in

A.M. Mohanty, Department of Mechanical Engineering, Centurion University of Technology and Management, Odisha, India, Email: provc@cutm.ac.in

(c) The Authors. Published by Blue Eyes Intelligence Engineering and Sciences Publication (BEIESP). This is an open access article under the CC BY-NC-ND license (http://creativecommons.org/licenses/by-nc-nd/4.0/)
Due to dependency on an additional labour and irregularity with labour turning up for work, labour has become a major operational challenge for blacksmith resulting in loss of income. Even though there are motorized blowers available in the market they are very inefficient (attached with $0.25 \mathrm{hp}$ motor) and as most of the blacksmith workshops are not connected to grid supply most of them would still be dependent on traditional bellows or hand cranked blowers. Even if the blacksmith workshops are connected to grid, due to erratic power cuts in rural areas, these blowers won't be useful to full extent instead it further increases uncertainty with labour planning and productivity. Hence there is a need for developing an efficient, reliable, cost effective solution for the blower requirement of blacksmiths.

Properly designed energy efficient blower requires about 92\% lesser energy for operation compared to motorized blowers available in the market. Hence the solar powered blower solution is very cost effective and has an attractive payback period of 2-3 months considering the additional labour cost alone thus reassuring better livelihood for blacksmiths. The main component of solar operated blower is solar panel, charge controller, battery, speed controller.

\section{SITE SURVEY}

Before installation of solar Photovoltaic System a proper site survey is essential. The following are the site assessment tools.

1. Checklist tools-(i).Compass, (ii) Measuring Tap, (iii) Solar Path Finder, (iv) Solar meter/Pyranometer/Lux meter

Site assessment: -

1. Prepare layout of building

2. Mark places available with shading for inverters \&batteries

3. Mark the dimension \& direction of roof

4. Enquire whether the obstruction can be moved or not

5. Take multiple photographs from different direction

6. Take 2 or 3 of the most suitable available spots on the roof installing photo voltaic array as a reference point.

7. Check the type of mounting structure required for different types of roof

8. RCC roof (normal) (existing pillar \& column position)

9. RCC roof (Elevated)

10. Galvanized sheet mounted roof (where the turbo vent \& skylight present) 
11. Check the orientation of building whether it is south facing

12. Exact latitude \& longitude details

13. Performing shading analysis

\section{LITERATURE REVIEW}

Under load condition, Shen [1] had done the optimization for sizing of solar array and battery in standalone Photovoltaic system in Malaysian weather condition and had calculated the loss of power supply probability of Solar Photovoltaic system. Zahab et al. [2] developed a standalone PV water pumping system which consists of PV panel, lead acid battery, and a water pump driven by brush less DC motor. There were three main controller used named as speed controller, MPPT (maximum power point tracking System) and controller for charging and discharging of battery. Kumar and Dalal [3] had done modeling of Solar Photovoltaic Pumping system using MATLAB. He had done a comparative test by using two MPPT algorithms using actual solar light intensity data in a two different weather condition. .He had got result that by using MPPT technique, the performance of Solar pumping system will increase as compared without uses of it. Arrouf and Ghabrour [4] had done simulation model of solar photovoltaic pumping system by using photovoltaic generator. Mellit et al. [5] had proposed a model regarding adaptive neuro fuzzy inference system and artificial neural network for estimating sequence of monthly clearness index and also got solar radiation data in different geographical location by taking different latitude, longitude data as input. Yadav et al. [6] had done investigation of energy efficiency on solar photovoltaic water pumping system by considering various parameters such as temperature, solar radiation and water head. He had two methods to find the optimum result such as best efficiency point and solar operational duty head. Korpale et al. [7] had done an experiment by comparison of two different types of water pumping system (solar operated water pumping and conventional water pumping system).He found that efficiency is more in solar based as compared to conventional method. Behera [8] had developed a solar operated pesticide sprayer which consists of charge controller, battery, solar panel and DC motor. Poudel et al. [9] designed semi automatic pesticide sprayer which was operated by wireless remote and micro controller and maximum discharge rate 0.556 liters/minute.

\section{DESIGN AND CALCULATION}

The catia design of PV panel, battery, charge controller and casing of dc blower was done.

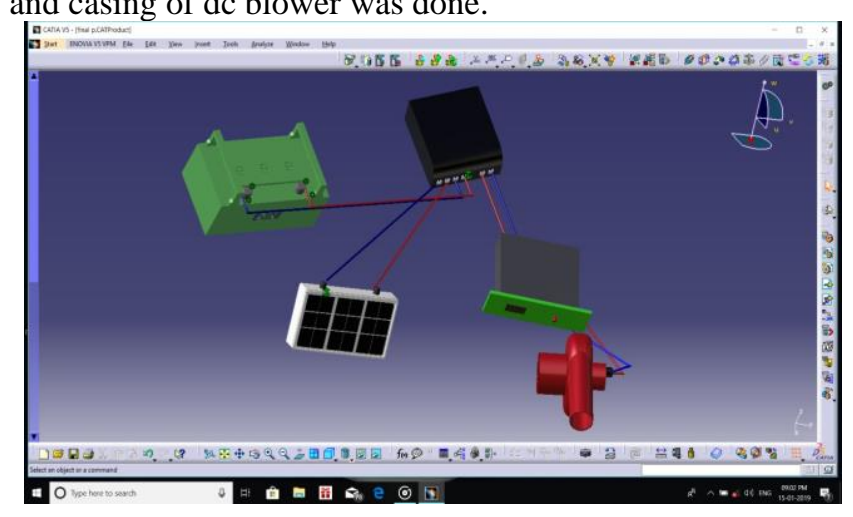

Figure 1. Catia design of solar operated Blower

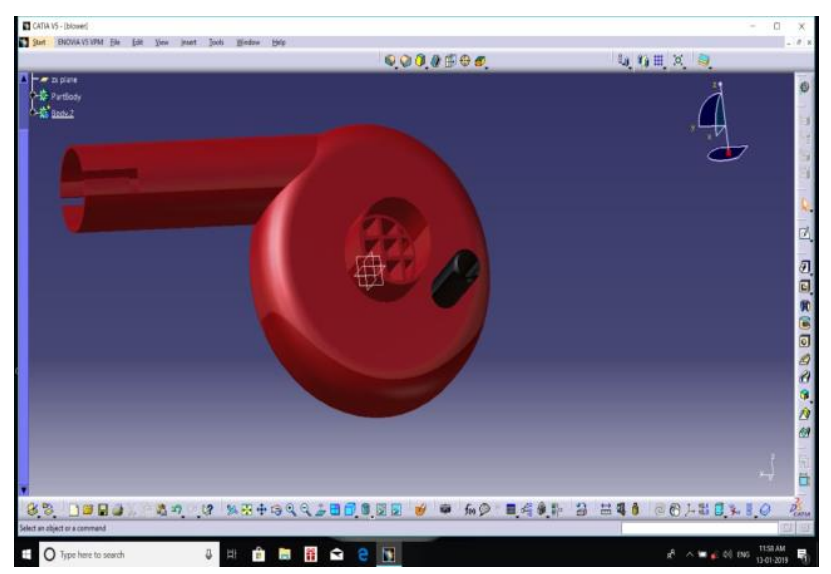

Figure 2. Catia design of centrifugal type DC blower

\section{CALCULATION}

The calculation has been done on the assumption of 5 hours sunshine.

\section{A.Sizing of PV panel}

Load calculation $=15 \mathrm{~W}$ DC blower $\times 5 \mathrm{~h}+30 \mathrm{~W}$-hr speed controller $=105 \mathrm{Wh}$

For climate condition total load $=105+105=210 \mathrm{Wh}$

So the size of the panel is obtained as;

$210 \mathrm{Wh} / 5=42 \mathrm{~W}$ panel.

Therefore, a standard size panel of $40 \mathrm{~W}$ may be considered.

\section{B .Sizing of battery}

12 volt battery is required for 3 to $100 \mathrm{~W}$ panel.

So the size of the battery is calculated as;

$210 \mathrm{Wh} / 12=17.5 \mathrm{Ah}=20 \mathrm{Ah}$

\section{Sizing of charge controller}

The size of the charge controller $=42 \mathrm{~W} / 12 \mathrm{~V}=3.5 \mathrm{~A}=$ $10 \mathrm{~A}$

\section{WORKING PRINCIPLE}

Before installation of Solar PV system, a proper site survey was done and a proper shadow free location was found. The solar photovoltaic panel, charge controller, battery, PWM speed controller, DC blower were electrically connected as shown below in the figure (3) of schematic diagram. A proper mounting structure was fabricated in order to install PV panel. It was tilted with $20^{\circ}$ according to latitude of that location facing due south for getting maximum amount of solar radiation incident on. Sizing of PV panel, charge controller and battery. By using pulse width modulation speed controller, the supplement of air can be regulated. The casing of DC blower was made centrifugal type. The specifications of different components have been already mentioned in the table 1.A proper furnace was fabricated for forging operation. 


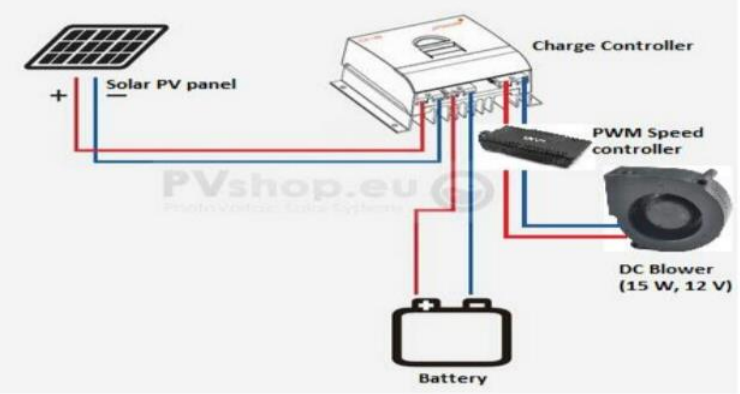

Figure 3. Electrical schematic diagram of solar powered blower

Table 1. Specifications of solar operated blower

\begin{tabular}{cll}
\hline S.N. & \multicolumn{1}{c}{ Parameter } & Specifications \\
\hline 1 & Solar panel & Maximum power 40 W, \\
& & $\mathrm{V}_{\mathrm{mp}}=18.3937 \mathrm{~V}, \mathrm{I}_{\mathrm{mp}}=2.3418 \mathrm{~A}$ \\
2 & Battery & $12 \mathrm{~V}, 20 \mathrm{Ah}$ \\
3 & Charge controller & $12 \mathrm{~V}, 10 \mathrm{~A}$ \\
4 & MCB switch & $61 \mathrm{DC} / 10 \mathrm{~A}, \mathrm{IP}$ \\
5 & Centrifugal casing & $15 \mathrm{~W}, 12 \mathrm{~V}$ \\
& type DC blower & \\
& integrated with DC & \\
& motor, & \\
6 & PWM speed controller & $30 \mathrm{~W}, 12 \mathrm{~V}$ \\
\hline
\end{tabular}

\section{RESULT}

For getting maximum output, the PV Panel was installed in shadow free location. It was mounted with a structure and was tilted with latitude of the location (Bhubaneswar latitude, $20^{\circ} \mathrm{N}$ to $85^{\circ}$ E).The observation was taken throughout the day for getting output with the variation of tilt angle. For getting maximum power output it was installed in a shadow free location and proper site survey was conducted.

Table 2. Power output of solar Photo voltaic Panel at different tilt angles

\begin{tabular}{ccccccc}
\hline & \multicolumn{7}{c}{ Light } & $\begin{array}{c}\text { Open } \\
\text { circuit } \\
\text { Inten } \\
\text { sity } \\
\text { v }\end{array}$ & $\begin{array}{c}\text { Tilt } \\
\text { angle } \\
\text { (deg) }\end{array}$ & $\begin{array}{c}\text { Time in } \\
\text { hour }\end{array}$ & $\begin{array}{c}\text { Short } \\
\text { circuit } \\
\text { (lux) }\end{array}$ & $\begin{array}{c}\text { Power } \\
\text { (V) } \\
\text { output } \\
\text { (Amp) }\end{array}$ & \begin{tabular}{c} 
(W) \\
\hline 1
\end{tabular} & $25^{0}$ & $11: 47 \mathrm{AM}$ & 1272 & 20.8 & 2.15 & 44.72 \\
2 & $45^{0}$ & $12: 30 \mathrm{PM}$ & 1421 & 17.7 & 1.31 & 23.187 \\
3 & $65^{0}$ & $1 \mathrm{PM}$ & 9346 & 18.3 & 1.85 & 33.85 \\
4 & $80^{\circ}$ & $1.30 \mathrm{PM}$ & 6766 & 19.01 & 1.33 & 25.28 \\
5 & $90^{\circ}$ & $2 \mathrm{PM}$ & 2864 & 18.3 & 1.61 & 29.463 \\
\hline
\end{tabular}

A. Calculation of efficiency of Solar Panel

The solar cell efficiency will be calculated by taking the relation:

Efficiency = maximum output power/ input power

Where, Input power $=$ Solar Irradiance $\times$ Area of solar panel

$$
=1000 \mathrm{~W} / \mathrm{m}^{2} \times 0.2544 \mathrm{~m}^{2}=254.4 \mathrm{~W}
$$

Performance parameters are under standard test conditions at irradiance of $1000 \mathrm{~W} / \mathrm{m}^{2}$ and cell temperature at $25^{\circ} \mathrm{C}$.

Efficiency of solar panel $=44.72 / 254.4=17.57 \%$ in a cleared sunny day with optimum tilt angle at $25^{\circ}$.

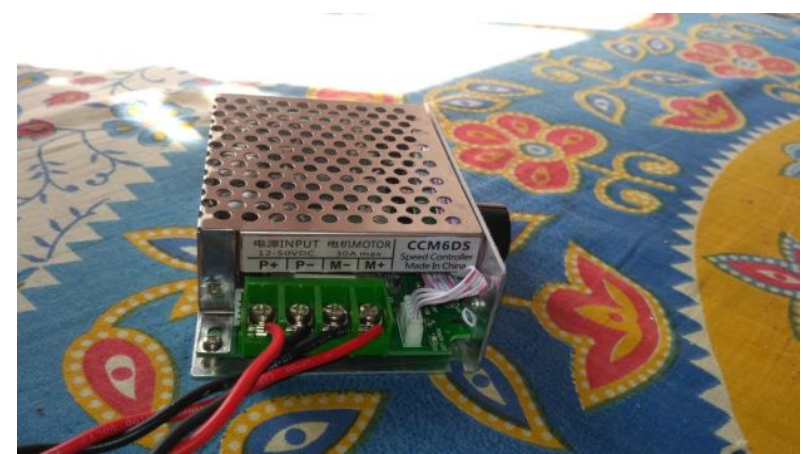

Figure 4. Connection of speed controller

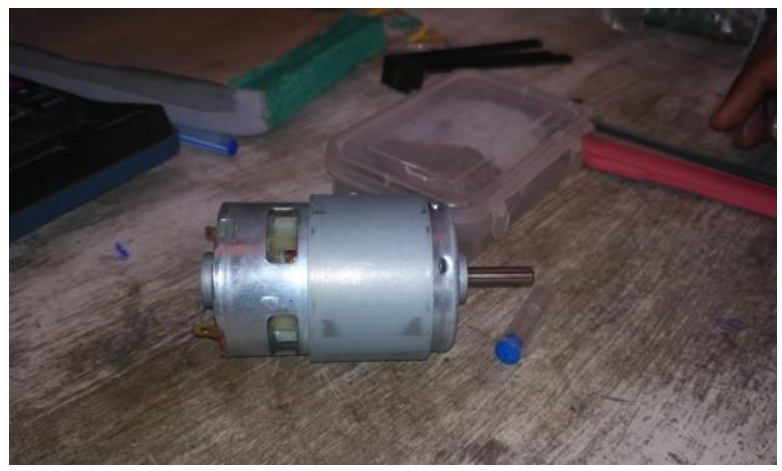

Figure 5. DC motor

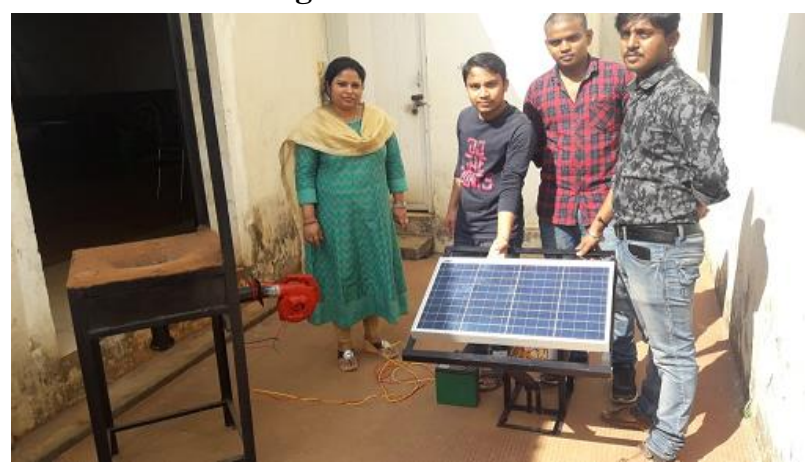

Figure 6. Full assembly of solar operated blower for forging operation

\section{DISCUSSION}

1. From the above experiment we have concluded that, if the tilt angle will be changed, the power output of PV panel will be affected. So panel should be tilted according to latitude of that location. As the Bhubaneswar latitude is $20^{\circ} \mathrm{N}$ to $85^{\circ} \mathrm{E}$, then panel should be tilted $20^{\circ}$ and it should be facing due south.

2. Table 2 shows the performance testing of a Photo voltaic panel with the variation of tilt angle. It has been observed that with $25^{\circ}$ tilt angle the maximum power out was obtained. The intensity of light was measure in lux by lux meter and open circuit voltage and short circuit current was measured by multimeter. It was found that forging operation was done automatically by connecting DC blower as compared to conventional method.

3. Due to the connection of Speed controller, there was a proper regulation of supplement of air by blower for which forging operation was quick and easy. 


\section{CONCLUSION}

1. The method used here to build solar powered blower system is cost effective comparatively to an electrically operated blower. This can be used during there was no sufficient amount of sunlight will be available.

2. The solar operated blower will help the workers of those remote areas of country. They can perform their regular work as well as saves charcoals up to large extent. At the same time they can do their blacksmith work with very less environment pollution.

3. By using Speed controller, the sufficient and regulated amount of air can be supplied for forging operation which was main advantage.

4. By using charge controller and battery gives 24 hours backup and also make possible to use in night purpose.

\section{REFERENCES}

1. W.X. Shen., "Optimally sizing of solar array and battery in a standalone Photovoltaic system in Malaysia", Renewable Energy, vol.34, 2009, pp.348-352.

2. Essam E. Aboul Zahaba, Aziza M.Zakib and Mohamed M.EI-Sotouhy, "Design and control of a Standalone PV water pumping system", Journal of Electrical system and Information Technology, vol.4, 2017, pp.322-337.

3. Kumar R. and Dalal G.K., "Design and Simulation of Photovoltaic Water Pumping System", International Journal of Science and Research, 2014, pp. 2208-2213.

4. Arrouf M. and Ghabrour S., "Modeling and Simulation of a Pumping System fed by photovoltaic generator within the Matlab/Simulink programming Environment", Desalination, vol.209, 2007, pp. 23-30.

5. Mellit A., Kalogirou S.A., Shaari S., Salhi S., and Arab Hadj A., "Methodology for Predicting sequences of mean monthly clearness index and daily solar radiation data in remote areas: Application for sizing of stand-alone PV system", Renewable Energy, 2008, pp.1570-1590.

6. Yadav K., Kumar A., Sastry O.S., and Wandhare R., "Solar Photovoltaic Pumps operating head selection for the optimum efficiency", Renewable Energy, 2019, pp. 169-177.

7. Korpale V.S., Kokate D.H., and Deshmukh S.P., "Performance Assessment of Solar Agricultural Water Pumping System", International Conference on Advances in Energy Research, 2015, pp. 518-524.

8. Behera D.D., "Development And Performance Testing of Solar Operated Insecticide And Pesticide Agro Spraying System", International Journal of Engineering and Advanced Technology, Volume 9, Issue 1,2019,pp.573-578.

9. Poudel B., Sapkota R., Shah R., Subedi N., and Krishna A. "Design and Fabrication of Solar Powered Semi Automatic Pesticide Sprayer", International Research Journal of Engineering and Technology, 2017, pp.2073-2077.

\section{AUTHORS PROFILE}

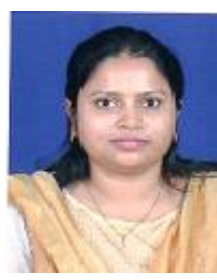

Debashree Debadatta Behera, Currently working as an Assistant Professor in the Department of Mechanical Engineering, Centurion University of Technology and Management, Odisha, India. She had qualified assessment test under Skill Council for Green jobs for Suryamitra Master Training Programme in Domain Skills and Platform Skills. She has done 3 journal publications.

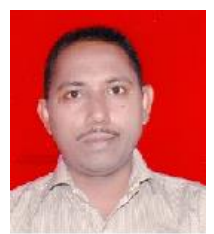

Dr. R.C. Mohanty, currently working as a Professor in the Department of Mechanical Engineering, Centurion University of Technology and Management, Odisha, India. He has more than 50 publications in national/international journals.

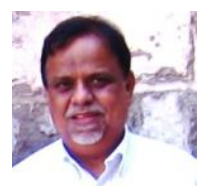

Dr. A.M. Mohanty, currently working as Pro-vice Chancellor in the Department of Mechanical Engineering, Centurion University of Technology and Management, Odisha. He has more than 100 publications in national/international journals. 